\title{
Malabsorption Syndrome in Paget's Disease of Bone
}

\author{
B. N. SOMAYAJI,* M.B., M.R.C.P., M.R.C.P.GLASG.
}

Brit. med. f., 1968, 4, 278-280

\begin{abstract}
Cummary : Of eight patients with Paget's disease one had diarrhoea, steatorrhoea, impaired xylose absorption, and macrocytic anaemia due to folic acid deficiency, while another had diarrhoea and very low xylose absorption. In both patients jejunal biopsy was normal, and they responded to folic acid therapy with considerable increase in xylose absorption. Low xylose excretion was seen in three more patients, one of whom also had steatorrhoea. Thus malabsorption may be a systemic complication of Paget's disease of bone, possibly due either to secondary folate deficiency or to relative ischaemia of the bowel.
\end{abstract}

\section{Introduction}

The morbidity of Paget's disease of bone, well described by Sir James Paget (Paget, 1877, 1882, 1889), is mainly due to the local effects of disordered bone structure such as fractures, deformities, pressure phenomena, and platybasia. However, when the disease is extensive and active it can affect the systemic circulation and give rise to high-output cardiac failure (Edholm et al., 1945 ; Sornberger and Smedal, 1952). A further systemic effect, a disturbance of calcium metabolism, may be produced by prolonged rest or immobilization after a fracture. The finding of malabsorption in a patient with extensive Paget's disease prompted a search for this complication in others, and the purpose of this paper is to describe the results and to draw attention to a possible new systemic complication of Paget's disease of bone.

\section{Patients and Methods}

Eight patients with Paget's disease have been studied. There were three men and five women, ranging in age from 57 to 82 years. Two were transferred from a near-by geriatric hospital and four, who were attending the outpatient clinic because of Paget's disease, agreed to admission for further investigations. The remaining two patients were admitted for the investigation of diarrhoea.

Routine haematological and biochemical investigations were carried out. $X$-ray examination of the chest, skull, and pelvis was done in all the patients. Further radiological examination depended on the presence of skeletal deformity or pain. In addition the following special investigations were performed:

Serum vitamin- $B_{12}$ concentration was measured according to the method of Matthews (1962), Lactobacillus leichmannii being used as the test organism.

Serum folate activity was determined with $L$. casei according to the "aseptic addition method" (Herbert, 1966).

Faecal fat excretion was measured by the method of van de Kamer et al. (1949). The test was done when the patients were on an ordinary hospital diet, which contained about $100 \mathrm{~g}$. of fat per day. The faeces were collected for 72 hours.

D-Xylose Absorption.-The patients were fasted overnight, but water intake was not restricted. In the morning, after voluntary emptying of the bladder, an oral dose of $25 \mathrm{~g}$. of D-xylose in $250 \mathrm{ml}$. of water was given and urine was collected for five hours. During this period solid food, but not water, was withheld. Urinary xylose

* Department of Medicine, Dudley Road Hospital, Birmingham 18 Present address: Department of Medicine. the University of Texas, Present address: Department of Medicine. the University of Texas, U.S.A. was estimated according to the method of Roe and Rice (1948). In the last three patients a modified method was used, an oral dose of $5 \mathrm{~g}$. of D-xylose being given and the two-hour and five-hour urinary excretion measured, in an attempt to localize the intestinal defect (Sammons et al., 1967).

Peroral Mucosal Biopsy of Small Intestine.-A specimen was obtained from the first few inches of jejunum by means of a multiple biopsy tube (Choudhury et al., 1964), the position of the capsule being determined radiologically. The biopsy specimens were first examined under the dissecting microscope after previous orientation and fixation in formol saline. They were prepared for histological examination by the usual methods.

\section{Results}

Two patients had abdominal symptoms, mainly in the form of anorexia, pain, vomiting, and diarrhoea. Serum alkaline phosphatase was more than $45 \mathrm{King}$-Armstrong (K.A.) units in all patients except one case (Case 2) (see Table). Serum calcium was low in both patients with diarrhoea (Cases 1 and 8), it was slightly elevated in two cases (Cases 2 and 6), and in the others it was within the normal range. Serum phosphate and blood urea were normal in all patients and none had proteinuria. Serum iron was less than $80 \mu \mathrm{g} . / 100 \mathrm{ml}$. in Cases 3,7 , and 8 . Serum $B_{12}$ was within the normal range in all patients, though it was low normal (112 and $100 \mu \mu \mathrm{g}$./ ml.) in the two patients who had abdominal symptoms. A very low serum folate level $(1.5 \mathrm{~m} \mu \mathrm{g} . / \mathrm{ml}$.), associated with a macrocytic anaemia, was present in Case 1 . In three patients the serum folate levels were low normal (Cases 3, 6, and 8), while in the others they were $5 \mathrm{~m} \mu \mathrm{g} . / \mathrm{ml}$. and above. Faecal fat excretion was raised in two patients (Cases 1 and 3 ), in both of whom the jejunal biopsy was normal. Jejunal biopsy done on a third patient was also normal (Case 8). Xylose excretion was very low in five patients (Cases $1,3,5,7$, and 8), two of whom also had steatorrhoea. Two-hour urinary xylose excretion, which was estimated in three patients, showed abnormally low values in two (Cases 7 and 8). There was no correlation between serum folate levels and xylose excretion.

Folic acid was given to the two patients with abdominal symptoms, with complete relief. In both cases xylose absorption also improved considerably, and faecal fat excretion fell to normal values in one (Case 1). Clinical details of these two patients are given below.

\section{Case 1}

A 57-year-old man was admitted to hospital in March 1966 for the investigation of recent deterioration in general health and loss the previous six months. He complained of weight of of anorexia, nausea with occasion to food and relieved by alkalis. pain, which was sometimes related to food and relieved by alkalis. In addition, in the previous month he had begun to pass loose stools, three to six times a day without any mucus or blood. A barium-meal examination, done as an outpatient, was normal.

He had suffered from Paget's disease since April 1961, when he first complained of pain in the shoulders, elbows, wrists, and forefirst complaincd oxamination showed an enlarged deformed clavicle on the right side. Bony prominences were also noted around the elbows and in the lower forearm on the left side. The affected bones were warm. His blood pressure (B.P.) was $160 / 90 \mathrm{~mm}$. Hg. X-ray were warm. His blood pressure (B.P.) was examination showed changes due to Paget's disease in the right scapula, clavicle, and head of humerus, both radii and ulnae, pelvis,
and femora. On $x$-ray examination the hands and skull were found 
Clinical and Laboratory Findings

\begin{tabular}{|c|c|c|c|c|c|c|c|c|c|c|c|c|c|c|}
\hline \multirow[b]{2}{*}{$\begin{array}{l}\text { Case } \\
\text { No. }\end{array}$} & \multirow[b]{2}{*}{$\begin{array}{l}\text { Age } \\
\text { and } \\
\text { Sex }\end{array}$} & \multirow[b]{2}{*}{$\begin{array}{l}\text { Bones Affected by } \\
\text { Paget's Disease }\end{array}$} & \multirow{2}{*}{$\begin{array}{c}\text { Serum } \\
\text { Alka- } \\
\text { line } \\
\text { Phos- } \\
\text { phatase } \\
\text { (K.A. } \\
\text { u./ } \\
100 \mathrm{ml} .) \\
\end{array}$} & \multirow[b]{2}{*}{$\begin{array}{c}\text { Serum } \\
\text { Calcium } \\
(\mathrm{mg} . / \\
100 \mathrm{ml} .)\end{array}$} & \multirow{2}{*}{$\begin{array}{c}\text { Serum } \\
\text { In- } \\
\text { organic } \\
\text { Phos- } \\
\text { phate } \\
\text { (mg./ } \\
100 \mathrm{ml} .)\end{array}$} & \multirow[b]{2}{*}{$\begin{array}{c}\text { Faecal } \\
\text { Fat } \\
\text { Excre- } \\
\text { tion } \\
\text { (g./day) }\end{array}$} & \multicolumn{2}{|c|}{ Urinary Xylose } & \multirow[b]{2}{*}{$\begin{array}{c}\text { Serum } \\
\text { Iron } \\
(\mu \mathrm{g} .1 \\
100 \mathrm{ml} .)\end{array}$} & \multirow[b]{2}{*}{$\begin{array}{c}\text { Serum } \\
\mathrm{B}_{12} \\
(\boldsymbol{\mu \mu \mathrm { g } .} / \\
\mathrm{ml} .)\end{array}$} & \multirow[b]{2}{*}{$\begin{array}{l}\text { Serum } \\
\text { Folate } \\
(\mathrm{m} \mu \mathrm{g} . / \\
\mathrm{ml} .)\end{array}$} & \multirow[b]{2}{*}{$\begin{array}{c}\mathrm{Hb} \\
(\mathrm{g} . / \\
100 \mathrm{ml} .)\end{array}$} & \multirow[b]{2}{*}{$\begin{array}{c}\text { Blood } \\
\text { Urea } \\
\text { (mg.l } \\
100 \\
\text { ml.) }\end{array}$} & \multirow[b]{2}{*}{ Comments } \\
\hline & & & & & & & $\begin{array}{c}2 \text { Hour } \\
(\% \\
\text { Dose) }\end{array}$ & $\begin{array}{c}5 \text { Hour } \\
(\% \\
\text { Dose) }\end{array}$ & & & & & & \\
\hline 1 & $57 \mathrm{M}$ & $\begin{array}{l}\text { Pelvis, femora, right scapula, } \\
\text { humerus, clavicle and } \\
\text { tibia, both radiiand ulnae, } \\
\text { skull, and lumbar vertebrae }\end{array}$ & $73 \cdot 7$ & $8 \cdot 3$ & $4 \cdot 0$ & 10.5 & - & $0.6 t$ & 108 & 112 & 1.5 & $6 \cdot 1$ & 17 & $\begin{array}{l}\text { Macrocytic anaemia } \\
\text { normal Schilling, } \\
\text { normal jejunal } \\
\text { biopsy }\end{array}$ \\
\hline 2 & $64 M$ & $\begin{array}{l}\text { Pelvis, tibia, and fibula on } \\
\text { both sides }\end{array}$ & $31 \cdot 5$ & $10 \cdot 9$ & $3 \cdot 3$ & $4 \cdot 7$ & - & $22 \cdot 4$ & 154 & 225 & $5 \cdot 0$ & $13 \cdot 5$ & 18 & $e^{0.00 y}-$ \\
\hline 3 & $82 \mathrm{~F}$ & $\begin{array}{l}\text { both s1des } \\
\text { Pelvis, femora, and skull }\end{array}$ & $45 \cdot 6$ & $9 \cdot 4$ & $4 \cdot 0$ & $9 \cdot 5$ & - & $7 \cdot 6$ & 40 & 225 & 3.5 & $13 \cdot 3$ & 35 & $\begin{array}{l}\text { Fracture right femur } \\
4 \text { years ago, normal } \\
\text { jejunal biopsy }\end{array}$ \\
\hline 4 & $76 \mathrm{~F}$ & $\begin{array}{l}\text { Lower ends of both femora, } \\
\text { lumbar vertebrae }\end{array}$ & $131 \cdot 0$ & - & - & $4 \cdot 0$ & - & $20 \cdot 8$ & 155 & 220 & $7 \cdot 8$ & $11 \cdot 6$ & 28 & jejunal biopsy \\
\hline 5 & $57 \mathrm{~F}$ & $\begin{array}{l}\text { Skull, left humerus, right } \\
\text { femur and tibia, pelvis, } \\
\text { lower dorsal and lumbar } \\
\text { vertebrae. }\end{array}$ & $156 \cdot 6$ & $10 \cdot 4$ & $4 \cdot 0$ & $2 \cdot 6$ & - & $6 \cdot 8$ & 175 & 133 & $11 \cdot 1$ & $13 \cdot 5$ & 37 & $\begin{array}{l}\text { Basilar invagination } \\
\text { and bilateral nerve } \\
\text { deafness }\end{array}$ \\
\hline 6 & $63 \mathrm{~F}$ & $\begin{array}{l}\text { Skull, pelvis, both femora, } \\
\text { and right humerus }\end{array}$ & $50 \cdot 2$ & $10 \cdot 9$ & $3 \cdot 0$ & $2 \cdot 8$ & $28 \cdot 0^{*}$ & $39 \cdot 0^{*}$ & 135 & 375 & $4 \cdot 0$ & $11 \cdot 6$ & 29 & - \\
\hline 7 & $78 \mathrm{M}$ & $\begin{array}{c}\text { Skull, pelvis, tibiae, fibulae, } \\
\text { scapulae, and clavicles }\end{array}$ & $110 \cdot 0$ & $9 \cdot 4$ & 4.5 & $4 \cdot 1$ & $4 \cdot 0^{*}$ & $14 \cdot 6 *$ & 25 & 260 & $8 \cdot 2$ & $10 \cdot 9$ & 42 & $\begin{array}{l}\text { Stools repeatedly } \\
\text { negative for occult } \\
\text { blood }\end{array}$ \\
\hline \multirow[t]{2}{*}{8} & 66 F & $\begin{array}{l}\text { Pelvis, all lumbar and dorsal } \\
\text { vertebrae, right tibia, and } \\
\text { scapula }\end{array}$ & $98 \cdot 0$ & 8.9 & $4 \cdot 0$ & $3 \cdot 7$ & $3 \cdot 7^{*} t$ & $14 \cdot 1 * t$ & 76 & 100 & $4 \cdot 0$ & 13.5 & 31 & $\begin{array}{l}\text { Normal jejunal } \\
\text { biopsy }\end{array}$ \\
\hline & & Normal values: & $3 \cdot 5-15$ & $9 \cdot 2-10 \cdot 4$ & $2 \cdot 5-4 \cdot 5$ & $<5 \mathrm{~g}$ & $14-34$ & $\begin{array}{r}17-30 \\
23-48\end{array}$ & $80-200$ & $100-900$ & $3-18$ & $14 \cdot 5$ & $<45$ & 一 \\
\hline
\end{tabular}

* 5 g. xylose given. $25 \mathrm{~g}$. xylose given in others.
t Considerable increase in xylose absorption/excretion following folic acid therapy. See case reports.

to be normal. Haemoglobin (Hb) was $14.4 \mathrm{~g} . / 100 \mathrm{ml}$., white blood cells (W.B.C.) 5,200/cu. mm., erythrocyte sedimentation rate (E.S.R.) $26 \mathrm{~mm}$. in one hour (Westergren), uric acid $5.7 \mathrm{mg} . /$ $100 \mathrm{ml}$., Wassermann reaction (W.R.) negative, calcium $9.8 \mathrm{mg} . /$ $100 \mathrm{ml}$., phosphate $3.4 \mathrm{mg} . / 100 \mathrm{ml}$, alkaline phosphatase 76.2 K.A. units. As pain was not relieved by simple analgesics and phenylbutazone, he was given corticotrophin 60 units intramuscularly twice daily, later reduced to 40 units daily. Although there was some improvement initially, this did not last for more than a few weeks. He continued to have recurrent attacks of pain, predominantly in areas which showed changes of Paget's disease radiologically. The corticotrophin was gradually reduced and he was put on prednisone $5 \mathrm{mg}$. t.d.s. Sodium fluoride was tried, but he was unable to tolerate it because of vomiting. His disability was so severe that he could not return to work.

During the present admission he was ill and anaemic, with evidence of recent weight loss. His B.P. was $150 / 70$. He had no oedema. In addition to the previously noted enlargement of bones and deformities, he had bowing of the right tibia. He was still passing three to six loose stools a day. Investigations showed Hb 6.1 g. $/ 100$ ml., W.B.C. 3,000/cu. mm., with normal differential count, and E.S.R. $75 \mathrm{~mm}$. in one hour (Westergren). The majority of the red blood cells were macrocytic and normochromic. There was anisocytosis and poikilocytosis; some polymorphs were hypersegmented. Augmented histamine test meal showed free hydrochloric acid after histamine. The Schilling test was performed, $0.5 \mu \mathrm{Ci}$ of ${ }^{58} \mathrm{Co}$-labelled vitamin $\mathrm{B}_{12}$ being given, and the 24 -hour urinary excretion was $16.6 \%$ of the dose. Serum protein was $5.4 \mathrm{~g}$., albumin $2.98 \mathrm{~g}$., and gammaglobulin $0.66 \mathrm{~g} . / 100 \mathrm{ml}$. Other biochemical results are shown in the Table. Radiological appearances of the right clavicle, pelvis, and femora had been unchanged since 1961. Small-bowel meal showed a few dilated loops of bowel, where the average diameter was above the normal limits, the appearances being consistent with steatorrhoea, A jejunal biopsy showed digitate villi under the dissecting microscope, and no abnormality was detected on light microscopy.

He was given folic acid $10 \mathrm{mg}$. three times daily by mouth. Within a week his general condition improved considerably; he felt well, his appetite returned, and he was passing one formed motion a day. After 10 days the folic acid was reduced to $10 \mathrm{mg}$. daily. The xylose absorption test now showed a urinary excretion of $11 \%$ of the dose in five hours-an eighteenfold rise over the pretreatment level. He was discharged home at the end of April, the $\mathrm{Hb}$ then being $10.5 \mathrm{~g} . / 100 \mathrm{ml}$.

He continued to improve, gaining $6.5 \mathrm{~kg}$ in weight in three months. $\mathrm{His} \mathrm{Hb}$ rose to $11.8 \mathrm{~g} . / 100 \mathrm{ml}$., and improvement was maintained for another five months. In January 1967 his general condition deteriorated over a period of three to four weeks. He complained of severe pain over the right forchead and right arm. A swelling in the middle of the right arm, in the region of the humerus, was found to be tender, and there was tenderness also over the skull, where a bruit was easily heard in the right temporal region. $X$-ray examination showed malignant change in the humerus at the junction of the mid and lower thirds. Many osteolytic areas were present in the skull, right clavicle, pelvis, and femora. Serum alkaline phosphatase was now $2,626 \mathrm{~K}$.A. units and acid phosphatase $13.8 \mathrm{~K}$.A. units. He had no diarrhoea, and faecal fat excretion was $2.3 \mathrm{~g}$./ day. His general condition deteriorated gradually and he died at the beginning of May 1967.

At necropsy there was no evidence of malignancy in any of the internal organs. Prostate, gastrointestinal tract, lungs, and liver were normal. The skull was thickened generally, with many sof areas which on histological examination showed characteristic features of osteosarcoma in Paget's disease.

\section{Case 8}

A 66-year-old housewife was admitted to hospital in January 1968 for investigation of anorexia, epigastric pain, vomiting, and diarrhoea. She had had these symptoms for nearly six months and had lost about $6.5 \mathrm{~kg}$. in weight. She passed four to six loose stools a day, without any blood or mucus. She was known to have had Paget's disease for nearly 17 years. Physical examination showed marked bowing of the right tibia, which was warm. Her B.P. was $140 / 80$. Results of the various laboratory tests are shown in the Table. Gastric juice contained free acid. Barium-meal and follow-through examination did not reveal any abnormality. Examination of jejunal biopsy under the dissecting microscope showed that most of the villi were digitate and a few were leaves. Histological examination did not disclose any abnormality.

In view of the experience in Case 1, she was given oral folic acid $10 \mathrm{mg}$. three times daily. Most of her abdominal symptoms subsided within a week and diarrhoea disappeared. Repetition of the D-xylose absorption test on the tenth day showed a two-hour urinary excretion of $26 \%$ of the dose (a sevenfold rise over the pretreatment level) and a five-hour excretion of $88 \%$ (a sixfold rise).

She continued to improve after discharge from hospital. When reviewed in the outpatient clinic at the end of May 1968 she was quite well. She had no abdominal symptoms, her appetite was good and her bowels were rather constipated. Her only complaint was a dull ache in the right leg that had persisted for 17 years; there was no change in its quality or severity.

\section{Discussion}

The complex series of pathological changes affecting the bony tissue in Paget's disease are well described by Dodge (1966). 
They consist of osteoclastic resorption of existing bone, followed by osteoblastic regeneration of a primitive coarse-fibred bone lying in a highly vascular fibrous stroma. Heaney and Whedon (1958), by using radiocalcium $\left({ }^{45} \mathrm{Ca}\right)$, have shown an increased turnover rate of calcium, indicating an enhanced rate of bone formation and a shorter "bone-life" than normal. A recent extensive review (Deuxchaisnes and Krane, 1964) stated that " all the data indicate that the rates of resorption and formation of bone in active Paget's disease are higher than in any other bone disease."

It is now generally recognized that folate deficiency is not uncommon in conditions associated with increased cellular proliferation. Pregnancy, haemolytic anaemias, leukaemia, myeloproliferative disorders, chronic iron deficiency, rheumatoid arthritis, extensive psoriasis, and other skin diseases are some of the situations where it occurs (Brit. med. F., 1968). It would seem that extensive active Paget's disease of bone should be added, though in addition to an increased demand for the vitamin there may be an inadequate dietary intake-hardly surprising in view of the chronic disability caused by extensive disease.

The effect of folate deficiency on the small gut (one of the organs of the body with the most rapid cell turnover) is to interfere with normal regeneration of villi, and this, in turn, exacerbates folate deficiency by hindering absorption of folic acid (Chanarin, 1966-7). When the folate deficiency is corrected, considerable improvement in intestinal absorption may occur, which is shown dramatically in tropical sprue (Gardner and Perez-Santiago, 1958 ; Chanarin, 1966-7). The cessation of diarrhoea, the improvement in general health, and the increased xylose absorption in Cases 1 and 8 after folic acid therapy are in keeping with the known actions of folic acid.

It is noteworthy that in two out of three patients (Cases 7 and 8 ), in whom xylose absorption was assessed according to the modified method of Sammons et al. (1967), the two-hour urinary excretion was very low, suggesting malabsorption in the upper small bowel, which is the site of absorption of folic acid. Chanarin and Bennett (1962) found abnormal folic acid absorption in all patients who showed an abnormal xylose absorption. Therefore it is possible, but not proved, that malabsorption of folic acid is also a feature of some of the present patients.

Chanarin et al. (1959) found an increase in the rate of clearance of folic acid from plasma in two-thirds of subjects in late pregnancy, and it was concluded that this was due to folic acid deficiency. In malignant tumours, where there is increased cellular proliferation, an accelerated folate clearance in plasma is more characteristic than a low serum folate activity (Einhorn and Reizenstein, 1966). Seventeen out of 19 patients with early malignancy, in whom there was no known impairment of nutrition or deterioration in general condition, had an accelerated clearance, as compared with normal healthy controls. The serum folate activity in some patients was greater than $9 \mathrm{~m} \mu \mathrm{g}$./ $\mathrm{ml}$., the lower limit of normal being $3 \mathrm{~m} \mu \mathrm{g} . / \mathrm{ml}$. Similarly, in Paget's disease the serum folate level may not represent the actual tissue concentration or increased demand for the vitamin. This would explain the low normal or normal serum folate levels seen in all the patients except one (Case 1) in the present study. To elucidate this point further, studies involving plasma clearance of folate and estimation of red blood cell folate would be valuable.

In extensive active Paget's disease the bone blood flow may be increased up to twentyfold, effects on the general circulation being similar to those resulting from free arteriovenous communications (Edholm et al., 1945). Blood may well be diverted from the splanchnic circulation by this greatly increased peripheral blood flow, resulting in a relative ischaemia of the bowel, as in dermatogenic enteropathy (Lancet, 1965; Shuster and Marks, 1965). Reduction of splanchnic blood flow, produced by exercise in the heat, results in impairment of active absorption in the small bowel even in normal men (Williams et al.,
1964), and present evidence suggests that folate is one of those substances that are actively absorbed (Herbert, 1968). Thus it is possible that secondary folate deficiency and relative ischaemia are the two mechanisms responsible for the reversible smallbowel dysfunction in Paget's disease. Since folic acid therapy may correct the malabsorption even when there has not been any change in the circulatory state, the former is more likely to be the major aetiological factor in the pathogenesis of malabsorption.

It is well recognized that Paget's disease may be present in a subclinical form, and that it may affect only limited regions of the skeleton, only a single bone, or even part of a single bone. Though necropsy studies of the skeletons of unselected patients dying in hospital have revealed an incidence of 3\% (Schmorl, 1932 ) and $3.7 \%$ (Collins, 1956), the incidence of extensive disease is much lower. In one series, only four out of 54 patients had the "classic" form in which the skull, spine, pelvis, and extremities were widely involved (Sornberger and Smedal, 1952). Even where the disease is extensive the course is extremely variable. It may remain stationary for long periods or may spread gradually to produce extensive deformity, crippling, and rarely sarcomatous change, as in Case 1 of the present study. It is only when the disease is extensive and active that it affects the general circulation (Edholm et al., 1945; Sornberger and Smedal, 1952 ; Edholm and Howarth, 1953). Similarly, secondary folate deficiency, reduction in splanchnic blood flow, and malabsorption are to be expected only in those few patients who have extensive active disease.

Though a systematic skeletal survey has not been done, it seems that malabsorption of xylose is likely to be present in those patients who have the extensive and "classic" form of the disease (see Table). The number of patients studied is too small to draw any definite conclusions regarding the incidence of malabsorption, but, as in the case of cardiovascular changes, "the moderately advanced and classic forms of osteitis deformans are too uncommon to permit accumulation and study of a single statistically significant series of cases" (Sornberger and Smedal, 1952).

I am grateful to Dr. A. Paton for allowing me to study patients under his care and for helpful advice throughout this investigation. I should like to thank Dr. G. W. Hearn, Dr. B. McConkey, and Dr. L. Nagley for permission to study patients under their care, and $\mathrm{Mr}$. W. B. Yeoman for various biochemical investigations.

\section{REFERENCES}

Brit. med. F., 1968, 2, 377.

Chanarin, I.'(1966-7). F. roy. Coll. Phycns Lond., 1, 360

. Brit. med. f., 1, 985.

Chanarin, I., and Benbett, B. M., O'Sullivan, W. J., and Mollin, D. L. (1959). Lancet, 2, 634

(1964). Lancet, 2, 185 .

Collins, D. H. (1956). Lancet, 2, 51. 43, 233.

Dodge, O. G. (1966). In D. H. Collins's Pathology of Bone. London.

Edholm, O. G., and Howarth, S. (1953). Clin. Sci., 12, 277. . Sci., 5, Edholm, O. G., Howarth, S., and McMichael, J. (1945). Clin.

Einhorn, J., and Reizenstein, P. (1966). Cancer Res., 26, 340.

Einhorn, J., and Reizenstein, P. (1968). In Tropical Sprue, edited by W. W W

by W. H. Crosb. W. clin. Endocr., 18, 1246.

Heaney, R. P., and Whedon, G. D.

Herbert, V. (1966). F. clin. Path., 19, 12. 10.

Herbert, V. (1968).

Lancet, 1965, 2, 69. 6 (1962). Clin. Sci., 22, 101.

Matthews, D. M. (1962). Clin. Sci., 22, 101.

Paget, J. (1877). Med.-chir. Trans., 60, 37.

Paget,

Poe, J. H., and Rice, E. W. (1948). ł. biol. Chem., 173, 507

Roe, J. H., and Rice, E. W. (1948). F. Philip, W. M., and Phillips, M. J. (1967). Gut, 8, 348.

Philip, (1932). Virchows Arch. path. Anat., 283, 694.

Schmorl, G. (1932).

Shuster, S., and Marks, J. (1965) i. Lancet, 1, 1367.

Sornberger, C. F., and Smedal, M. I. (1952). Circulation, 6, 711. van de Kamer, J. H., Huinink,

Williams, J. H., jun., Mager, M., and Jacobson, E. D. (1964). F. Lab. clin. Med., 63, 853 . 